\title{
ANALISIS HARGA MINIMUM LAYAK DI TINGKAT PETANI ATAS GABAH KERING PANEN (GKP) DAN BERAS DI DESA PAHANG ASRI KECAMATAN BUAY PEMUKA PELIUNG KABUPATEN OKU TIMUR
}

\author{
(Sugeng Supriyanto)
}

\begin{abstract}
The objectives of this study were to: (1) Calculate what is the minimum feasible price at the farmer level for dry rice harvest and rice in Pahang Asri Village, (2) Compare the minimum price with the actual price (market price) on the sales of dry milled grain and rice. This research was conducted in Pahang Asri Village, Buay Pemuka Peliung District, OKU Timur District. Determining the location was done purposively, from 13 villages in Kecamatan Buay Pemuka Peliung only Pahang Asri Village selected by the researcher to conduct a research on analysis of minimum price of rice and rice with the consideration that in the village the only village that has a village regulation (Perdes) on rice yield management. Data collection at research location was conducted in March to June 2014 (Production data of planting season I, October 2013 - March 2014). The study found that the minimum average minimum rate at farmers' level for dry paddy harvest (GKP) is Rp.2.666 / $\mathrm{kg}$ and the minimum price is feasible at the farmer level on rice of Rp. $3.754,-/ \mathrm{kg}$. The two minimum prices at the farmers' level are lower than the actual price of $R p$ 3,217, - per $\mathrm{kg}$ for dry harvest (GKP) and Rp. 6.434, - per $\mathrm{kg}$ for rice. There is a difference between the actual price and the appropriate minimum price at the farmer level of dry unhulled rice (GKP). In the Paired Samples Statistic table, the average actual price of dry paddy harvest (GKP) is Rp.3.217,11 / $\mathrm{kg}$ and for the minimum price of dry paddy harvested (GKP) is Rp.2.666 / kg. This indicates that the actual price of dry paddy harvest $(G K P)$ is higher than the minimum price of dry paddy harvested (GKP).
\end{abstract}

Key Words : Production of Rice, Minimum Price Analysis, Income.

\section{PENDAHULUAN}

\section{A. Latar Belakang}

Peningkatan produksi padi ternyata belum mampu meningkatkan kesejahteraan petani. Sekitar 56,5 persen petani padi di Indonesia merupakan petani gurem. Penguasaan lahan usahatani padi oleh petani Indonesia rata-rata kurang dari 0,5 hektar, sehingga petani padi Indonesia digolongkan ke dalam kelompok masyarakat miskin (BPS, 2013). Kondisi ini ditambah dengan keterbatasan petani dalam mengakses berbagai layanan seperti pembiayaan usahatani serta sulitnya pemasaran produk panen petani.

Kabupaten OKU Timur sebagai salah satu daerah lumbung pangan di Propinsi Sumatera Selatan, terus melakukan upaya dalam rangka meningkatkan produksi dan produktivitas pertanian guna mewujudkan ketahangan pangan nasional. Langkah tersebut disertai dan ditunjang dengan pemanfaatan teknologi pertanian dan kebijakan Pemerintah Daerah Kabupaten OKU Timur yang tertuang dalam sasaran pembangunan pertanian tanaman pangan dengan sasaran produksi padi satu juta ton (Tabel 1) pada tahun 2013 (BPS, 2013).
Tabel 1. Sasaran dan Realisasi Luas Tanam, Luas Panen dan Produksi Padi Sawah di Kabupaten OKU Timur.

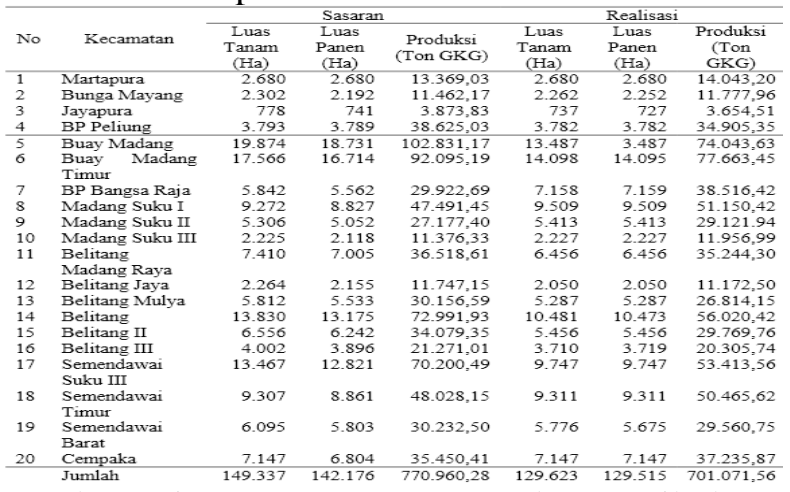

Sumber: Dinas Tanaman Pangan dan Hortikultura Kabupaten OKU Timur, 2013.

Kesejahteraan petani yang menjadi sasaran pembangunan pertanian perlu diperhatikan lebih serius. Petani sebagai pelaku yang berperan dalam meningkatkan produksi seharusnya mendapatkan perhatian terutama dari pemerintah. Petani selalu menjadi pihak yang dirugikan, dengan biaya produksi yang tinggi, tetapi tidak diimbangi dengan harga jual hasil panen yang tinggi sehingga pendapatan petani tidak meningkat atau bahkan tidak cukup untuk kebutuhan hidup sehari-hari mereka.

Kecamatan Buay Pemuka Peliung merupakan salah satu daerah penghasil padi di 
Kabupaten OKU Timur yang cukup berperan. Luas lahan sawah di daerah ini yaitu sebesar 3.782 hektar (BPS, 2013). Kecamatan ini mampu memasok sekitar 35 ribu ton gabah kering giling. Desa Pahang Asri memberikan kontribusi sebesar 10 persen dari jumlah tersebut. Desa ini merupakan satu-satunya desa di Kecamatan Buay Pemuka Peliung yang memliliki Peraturan Desa tentang pengelolaan hasil panen padi. Dalam Peraturan Desa tersebut, petani dilarang menjual hasil panennya dalam bentuk gabah kering panen maupun gabah kering giling kepada pedagang atau tengkulak dari luar desa. Petani harus memproses hasil panennya menjadi beras baru kemudian dapat dijual ke pedagang dari luar desa. Pengelolaan hasil panen ini dilakukan oleh kelompok lumbung pangan yang terdapat di desa ini. Kelompok lumbung pangan ini selain memproses hasil panen menjadi beras juga melakukan pembelian gabah dengan harga sesuai pasar.

Dalam sistem agribisnis padi, pada umumnya petani padi menjual gabah secara langsung kepada penjual besar atau tengkulak pada saat musim panen. Sebagian besar petani tidak mempunyai bangunan dan alat penyimpanan serta penggilingan padi sehingga proses tersebut dilakukan oleh pedagang besar. Ketika harga beras naik, maka pedagang-pedagang beras akan menikmati keuntungan dari kenaikan harga beras tersebut. Kondisi tersebut sangat menyulitkan petani terutama pada musim panen karena harga gabah yang sering anjlok. Ditambah lagi dengan masuknya beras impor yang menyebabkan harga beras dalam negeri turun dan semakin terpuruknya kondisi petani.

Pemerintah berusaha menolong petani dengan berbagai instrumen kebijakan. Salah satu kebijakan tersebut adalah dengan menetapkan Harga Pembelian Pemerintah (HPP) nasional terhadap gabah yang dulu dikenal dengan harga dasar gabah (HDG). Perubahan HDG menjadi HPP sangat mendasar karena dengan kebijakan HPP, pemerintah tidak lagi berkewajiban dan tanggung jawab formal dan juridis untuk menjamin harga dasar gabah pada tingkat harga tertentu, serta bukan menjamin harga dasar gabah minimum di tingkat petani sebagaimana lazimnya pada konsep kebijakan HDG. Dengan kewajiban HPP Pemerintah tidak wajib membeli gabah dari petani (Sopian, 2008).

Salah satu indikator tingkat kesejahteraan petani dan keadaan perekonomian pedesaan adalah nilai tukar petani (NTP). Nilai tukar petani (NTP) merupakan pengukur kemampuan/daya beli petani dalam membiayai kebutuhan hidup rumah tangganya. Perkembangan NTP diperlukan untuk memantau perkembangan kesejahteraan petani dari waktu ke waktu, baik petani secara agregat, wilayah maupun petani kelompok komoditas (Rahim, 2010).

Tabel 2. Perkembangan Nilai Tukar Petani Indonesia.

\begin{tabular}{llccccc}
\hline$N_{0}$ & \multicolumn{1}{c}{ Subsektor } & 2009 & $\mathbf{2 0 1 0}$ & $\mathbf{2 0 1 1}$ & $\mathbf{2 0 1 2}$ & $\mathbf{2 0 1 3}$ \\
\hline 1. & Tanaman Pangan & 95,09 & 97,80 & 102,83 & 104,71 & 104,65 \\
2. & Hortikultura & 103,38 & 107,64 & 108,95 & 109,03 & 107,62 \\
\hline
\end{tabular}

Sumber: Pusdatin, 2014.

Perkembangan NTP padi secara agregat di Indonesia berfluktuatif setiap tahunnya yang terlihat pada Tabel 2. Indeks NTP tertinggi dicapai pada tahun 2012 sebesar 104,71, sedangkan terendah terjadi pada tahun 2009 sebesar 95,09. Dengan demikian, NTP padi Indonesia dari tahun 2009 sampai 2012 mengalami peningkatan namun akhirnya sedikit menurun pada tahun 2013.

Data tahun 2013 menunjukkan indeks NTP subsektor tanaman pangan berada pada 104,65. Namun, indeks NTP subsektor tanaman pangan masih lebih rendah dibandingkan dengan NTP subsektor hortikultura. Indeks NTP subsektor tanaman pangan masih berkisar antara 95 sampai 105 berbeda dengan indeks NTP subsektor hortikultura yang berkisar antara 100 sampai 110 . Hal ini disebabkan nilai jual komoditi tanaman pangan lebih rendah dibandingkan tanaman hortikultura. Dapat dikatakan kesejahteraan petani tanaman pangan lebih rendah daripada petani hortikultura. Padahal tanaman pangan terutama beras merupakan komoditi yang paling penting di Indonesia karena merupakan bahan makanan pokok. Keadaan kesejahteraan petani yang masih rendah dari indeks NTPnya, membuktikan bahwa nilai jual padi atau gabah terlalu rendah.

\section{B. Rumusan Masalah}

1. Berapa harga minimum layak di tingkat petani atas gabah kering panen dan beras di Desa Pahang Asri.

2. Bagaimana perbedaan antara harga minimum layak dengan harga aktual (harga pasar) atas penjualan gabah kering giling dan beras.

\section{Tujuan dan Kegunaan}

1. Menghitung berapa harga minimum layak di tingkat petani atas gabah kering panen dan beras di Desa Pahang Asri. 
2. Membandingkan antara harga minimum layak dengan harga aktual (harga pasar) atas penjualan gabah kering giling dan beras.

\section{Model Pendekatan}

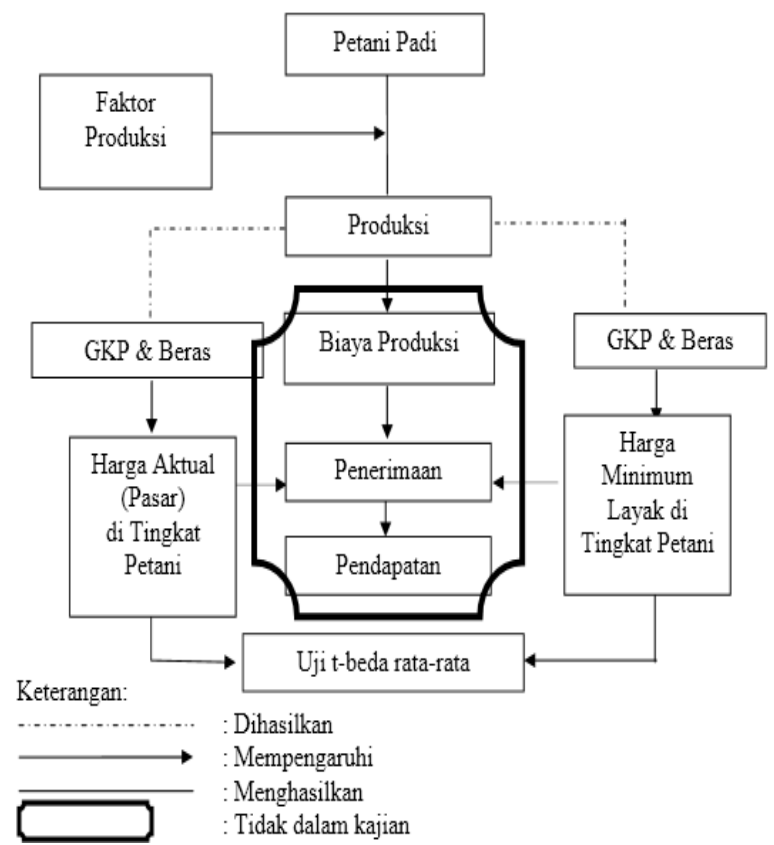

Gambar 1. Model pendekatan penelitian secara diagramatik

\section{METODOLOGI PENELITIAN}

\section{A. Tempat dan Waktu}

Penelitian ini telah dilaksanakan di Desa Pahang Asri Kecamatan Buay Pemuka Peliung Kabupaten OKU Timur. Penentuan lokasi dilakukan secara sengaja (purposive), dari 13 desa di Kecamatan Buay Pemuka Peliung hanya Desa Pahang Asri yang dipilih peneliti untuk melakukan penelitian tentang analisis harga minimum gabah dan beras dengan pertimbangan bahwa di desa tersebut satu-satunya desa yang telah memiliki peraturan desa (Perdes) tentang pengelolaan hasil panen padi. Pengumpulan data di lokasi penelitian dilaksanakan pada Bulan Maret sampai dengan Juni 2014 (Data produksi musim tanam I, Bulan Oktober 2013 - Maret 2014).

\section{B. Metode Penelitian}

Metode penelitian yang digunakan pada penelitian ini adalah metode survei. Metode survei merupakan suatu cara pendekatan dengan menggunakan teknik yang berhubungan dengan survei. Metode ini sering digunakan pada penelitian usahatani (Soekartawi, 2002).

\section{Metode Penarikan Contoh}

Metode penarikan contoh yang digunakan adalah metode Simple Random Sampling (SRS).

Metode ini diambil karena pada setiap usaha tani terdapat perbedaan populasi, dimana populasi yang diambil berjumlah 562 petani yang terdiri 301 petani yang menjual hasil panennya berupa gabah kering panen (GKP) dan 261 petani yang menjual hasil panennya berupa beras.

\section{Metode Pengolahan Data}

Data yang telah diperoleh dari lapangan diolah secara matematis, disajikan secara tabulasi, kemudian dijelaskan secara deskriptif kualitatif sesuai dengan tujuan penelitian ini.

Untuk menjawab tujuan pertama, yaitu menghitung harga minimum layak di tingkat petani atas gabah kering panen dan beras, maka data yang diperoleh di lapangan diolah dengan menggunakan pendekatan matematis sebagai berikut:

1. Menurut Soekartawi (2002), biaya produksi dihitung dengan menggunakan rumus:

$$
\mathrm{BP}=\mathrm{VC}+\mathrm{FC}
$$

Dimana:

$\mathrm{BP}=$ Biaya Produksi $(\mathrm{Rp} / \mathrm{ha} / \mathrm{Musim}$ Tanam $)$

$\mathrm{VC}=$ Variable Cost $(\mathrm{Rp} / \mathrm{ha} /$ Musim Tanam $)$

$\mathrm{FC}=$ Fix Cost $(\mathrm{Rp} / \mathrm{ha} / \mathrm{Musim}$ Tanam $)$

2. Menurut Suratiyah (2003), Break Event Point merupakan nilai dari titik impas, dimana usaha tersebut tidak mendapatkan untung atau rugi. Untuk mengetahui nilai tersebut dapat menggunakan rumus berikut ini:

- BEP Harga $(\mathrm{Rp})=\mathrm{TC} / \mathrm{Y}$

- $\mathrm{BEP}$ Produksi $=\mathrm{TC} / \mathrm{P}$

Ketrangan:

$\mathrm{TC}=$ Total Cost

$\mathrm{FC}=$ Fix Cost

$\mathrm{Y}=$ Yield/jumlah produksi

$\mathrm{P}=$ Price/Harga produk $(\mathrm{Rp} / \mathrm{Kg})$

3. Menurut Antoni (2006) Harga Minimum Layak (HML) dihitung dengan rumus:

$$
\mathrm{HML}=\frac{\mathrm{BP}+\left(\sum \mathrm{AK} \times \mathrm{KHM}\right)}{\mathrm{Q}}
$$

Dimana:

HML = Harga Minimum Layak

$\mathrm{BP}=$ Biaya Produksi (Rp/ha/Musim Tanam)

$\sum \mathrm{AK}=$ Jumlah Anggota Keluarga $(\mathrm{Org} / \mathrm{KK})$
$\mathrm{KHM}=$ Kebutuhan Hidup Minimum (Rp.718.400/org/bulan)

$\mathrm{Q}=$ Jumlah Produksi (Kg/Musim Tanam) 
Untuk menjawab tujuan kedua, yaitu membandingkan antara harga minimum layak di tingkat petani dengan harga aktual (harga pasar) atas penjualan gabah kering panen dan beras, dilakukan dengan menggunakan bantuan program aplikasi SPSS Versi 19, yaitu uji statistik beda rata-rata dua sampel berhubungan (Paired Sample $\mathrm{T}$ Test) dengan menggunakan sebaran t-student sebagai berikut:

$$
\mathrm{t}=\frac{\left(\mathrm{x}_{1}-\mathrm{x}_{2}\right)-}{\left(\mu_{1}-\mu_{2}\right)}
$$

Dimana :

$$
\begin{aligned}
& \mathrm{Sp}=\frac{\sqrt{(n 1-1) S 1^{2}+(n 2-1) S 2^{2}}}{\mathrm{n}_{1}+\mathrm{n}_{2}-2} \\
& \text { dan } \mathrm{db}=\mathrm{n}_{1}+\mathrm{n}_{2}-2
\end{aligned}
$$

Dengan hipotesis statistik sebagai berikut:

Ho : Tidak ada perbedaan antara harga aktual dan harga minimum layak di tingkat petani atas gabah kering panen (GKP) dan beras.

$\mathrm{Ha}$ : Ada perbedaan antara harga aktual dan harga minimum layak di tingkat petani atas gabah kering panen (GKP) dan beras.

\section{Kaidah keputusan :}

Apabila $t_{\text {hitung }}>t_{\text {tabel }}$ berarti antara harga aktual (harga pasar) dengan harga minimum layak di tingkat petani atas penjualan gabah kering panen dan beras berbeda secara signifikan. Sebaliknya apabila $t_{\text {hitung }} \leq t_{\text {tabel }}$ berarti tidak ada perbedaan antara harga aktual (harga pasar) dengan harga minimum layak di tingkat petani atas penjualan gabah kering panen dan beras.

\section{HASIL DAN PEMBAHASAN}

\section{A. Analisis Harga Minimal Layak di Tingkat Petani}

\section{Analisis Biaya Produksi}

Berdasarkan hasil penelitian, luas lahan rata-rata yang dimiliki petani contoh petani contoh yang menjual gabah kering panen (GKP) adalah sebesar 0,65 hektar. Luas lahan yang dimiliki ini semuanya digunakan untuk usahatani padi sawah. Data yang dianalisis adalah data usahatani padi yang dilaksanakan pada musim tanam I (Oktober 2013-Maret 2014).

Biaya produksi yang dikeluarkan oleh petani contoh di Desa Pahang Asri meliputi biaya tetap dan biaya variabel usahatani padi. Biaya tetap merupakan biaya yang dikeluarkan yang sifatnya tetap tidak tergantung dari besar kecilnya produksi. Hal ini sesuai dengan pendapat Soekartawi (1995) yang menyatakan bahwa biaya tetap umumnya didefenisikan sebagai biaya yang relatif tetap jumlahnya, dan terus dikeluarkan walaupun produksi yang diperoleh banyak atau sedikit. Jadi besarnya biaya tetap ini tidak tergantung pada besar kecilnya produksi yang diperoleh. Biaya tetap yang digunakan dalam analisis pada penelitian ini adalah biaya penyusutan alat-alat pertanian seperti cangkul, arit, alat penyiangan (gosrok), lory (gerobak dorong) handsprayer dan handtraktor.

Sedangkan biaya variabel merupakan biaya yang sifatnya berubah-ubah sesuai jumlah produksinya sehingga besar kecilnya biaya variabel akan ditentukan oleh besar kecilnya skala usaha dan produksi yang dihasilkan. Biaya variabel yang dikeluarkan oleh responden pada penelitian ini adalah tenaga kerja, benih, pupuk, dan pestisida. Untuk lebih jelasnya rata-rata biaya produksi yang dikeluarkan petani contoh dapat dilihat pada Tabel 3 di bawah ini.

Tabel 3. Rata-Rata Biaya Produksi Petani Padi Contoh di Desa Pahang Asri pada Musim Tanam I (Oktober 2013 - Maret 2014).

\begin{tabular}{llcc}
\hline No. & \multicolumn{1}{c}{ Jenis Biaya } & $\begin{array}{c}\text { Petani yang } \\
\text { Menjual Gabah } \\
\text { Kering Panen } \\
\text { (GKP) }\end{array}$ & $\begin{array}{c}\text { Petani yang } \\
\text { Menjual Beras }\end{array}$ \\
\hline 1. & $\begin{array}{l}\text { Biaya Tetap } \\
\text { - Biaya Penyusutan Pealatan }\end{array}$ & $152.321,23$ & $143.574,54$ \\
\hline & Total Biaya Tetap & $152.321,23$ & $143.574,54$ \\
\hline 2. & $\begin{array}{l}\text { Biaya Variabel } \\
\text { - Biaya Saprodi }\end{array}$ & $1.487 .631,58$ & $1.454 .394,74$ \\
& - Biaya Tenaga Kerja & $3.762 .889,57$ & $5.540 .641,29$ \\
\hline & Total Biaya Variabel & $5.250 .521,15$ & $6.995 .036,03$ \\
\hline 3. & $\begin{array}{l}\text { Rata-rata Biaya Produksi } \\
\text { (Rp/Luas Garapan) }\end{array}$ & $5.402 .842,38$ & $7.138 .610,57$ \\
\hline 4. & $\begin{array}{l}\text { Rata-rata Biaya Produksi } \\
\text { (Rp/Ha/MT) }\end{array}$ & $8.416 .120,30$ & $11.264 .352,57$ \\
\hline
\end{tabular}

Sumber : Data Primer diolah, 2014.

Berdasarkan tabel diatas, terdapat perbedaan rata-rata biaya tetap yang dikeluarkan petani contoh pada usahatani padi per musim tanam. Walaupun jenis alat yang digunakan petani yang menjual gabah kering panen (GKP) dan petani yang menjual beras adalah sama namun jumlah alat, lama umur ekonomis dan harga beli alat tersebut berbeda antara masing-masing petani. Begitu juga rata-rata biaya variabel usahatani padi terdapat perbedaan per musim tanam, perbedaan yang paling menonjol pada biaya tenaga kerja, hal 
ini terjadi karena terdapat penambahan biaya tenaga kerja pada petani contoh yang menjual beras yaitu tenaga kerja untuk penjemuran yang besarnya rata-rata Rp.10.000,-/100 kg GKP dan ongkos giling padi yang besarnya adalah 9 persen dari hasil beras yang dihasilkan.

\section{Hasil Produksi, Harga Aktual, dan Harga} Minimum Layak

Produksi dalam artian yang umum didefinisikan sebagai segala kegiatan yang ditujukan untuk menciptakan atau menambah guna atas suatu benda untuk memenuhi kebutuhan kepuasan manusia. Setiap proses untuk menghasilkan barang dan jasa dinamakan "Proses Produksi". Produksi dalam artian lebih "operasional" adalah suatu proses dimana satu atau beberapa barang dan jasa yang di sebut "input" diubah menjadi barang dan jasa yang di sebut "output" (Sumardjono, 2004). Pada penelitian ini, proses produksi dihitung selama 6 bulan (Oktober 2015-Maret 2016) dan output (hasil produksi)nya berupa gabah kering panen (GKP) dan beras.

Dalam perekonomian kita sekarang ini untuk mengadakan pertukaran atau untuk mengukur nilai suatu produk kita menggunakan uang, bukan sistem barter. Jumlah uang yang digunakan di dalam pertukaran tersebut mencerminkan tingkat harga dari suatu barang. Jadi, harga dapat didefinisikan sebagai sejumlah uang yang dibutuhkan untuk mendapatkan sejumlah barang. Harga merupakan komponen yang berpengaruh langsung terhadap laba perusahaan. Tingkat harga yang ditetapkan mempengaruhi kuantitas barang yang dijual. Selain itu secara tidak langsung harga juga mempengaruhi biaya, karena kuantitas yang terjual berpengaruh pada biaya yang ditimbulkan dalam kaitannya dengan efisiensi produksi. Oleh karena itu penetapan harga mempengaruhi pendapatan total dan biaya total, maka keputusan dan strategi penetapan harga memegang peranan penting dalam setiap perusahaan (Verina, 2001).

Sedangkan harga minimum layak di tingkat petani merupakan jumlah dari besarnya kebutuhan minimum per keluarga ditambah biaya produksi per kilogram dibagi jumlah produksi yang dihasilkan petani (Antoni, 2006).

Tabel 4. Rata-Rata Produksi, Harga Jual Aktual, Harga Minimum Layak dan Break Evev Poin (BEP) Harga di Tingkat Petani Atas Gabah Kering Panen (GKP) dan Beras di Desa Pahang Asri.

\begin{tabular}{llrr}
\hline No. & \multicolumn{1}{c}{ Uraian } & $\begin{array}{r}\text { Gabah Kering Panen } \\
\text { (GKP) }\end{array}$ & \multicolumn{1}{c}{ Beras } \\
\hline 1. & Produksi (Kg ha/MT) & 6.468 & 3.849 \\
2. Harga Jual Aktual (Rp/kg) & 3.217 & 6.434 \\
3. Biaya Produksi (Rp/Ha/MT) & $8.416 .120,30$ & $11.264 .352,57$ \\
4. Jumlah Anggota Keluarga (Org) & 5 & 4 \\
& Kebutuhan Hidup Minimum & 718.400 & 718.400 \\
5. (Rp/kapita bulan) & & \\
6. Harga Minimum Layak (Rp/kg) & 2.666 & 3.754 \\
7. Break Even Point (BEP) Harga & 1.303 & 2.929 \\
& (Rp/Kg) & & \\
\hline
\end{tabular}

Sumber : Data Primer diolah, 2014.

Berdasarkan tabel diatas, rata-rata produksi gabah kering panen (GKP) yang dihasilkan pada luasan rata-rata adalah sebesar $4.231 \mathrm{~kg}$ per musim tanam atau $6.468 \mathrm{~kg}$ per hektar per musim tanam, sedangkan beras yang dihasilkan adalah $2.413 \mathrm{~kg}$ per musim tanam atau $3.849 \mathrm{~kg}$ per hektar per musim tanam. Rata-rata harga jual gabah kering panen (GKP) adalah sebesar $\mathrm{Rp}$ 3.217 per $\mathrm{kg}$, sedangkan harga jual beras ratarata sebesar Rp. 6.434,- per kg. Dengan jumlah anggota keluarga rata-rata petani contoh sebanyak 5 orang dan 4 orang serta kebutuhan hidup minimum masyarakat di OKU Timur yang ditetapkan oleh BPS (2015) sebesar Rp. 718.400,per orang per bulan maka diperoleh rata-rata harga minimum layak di tingkat petani atas gabah kering panen (GKP) sebesar Rp.2.666/kg dan harga minimum layak di tingkat petani atas beras sebesar Rp. 3.784,-/kg. Sedangkan harga pada posisi Break Even Poin (BEP) sebesar Rp.1.303,-/kg untuk gabah kering panen (GKP) dan Rp. $2.929,-/ \mathrm{kg}$ untuk beras.

\section{B. Analisis Perbedaan Harga Aktual dan Harga Minimum Layak di Tingkat Petani Atas Gabah Kering Panen (GKP) dan Beras.}

Perbedaan harga diperoleh dari selisih harga aktual dengan harga minimu layak di tingkat petani dari petani yang menjual gabah kering panen (GKP) dan petani padi yang menjual beras. Untuk melihat perbandingannya dapat dilihat pada tabel berikut ;

Tabel 5. Rata- Rata Selisih Harga Aktual dan Harga Minimum Layak di Tingkat Petani atas Gabah Kering Panen (GKP) dan Beras di Desa Pahang Asri. 


\begin{tabular}{llrrr}
\hline \multirow{2}{*}{ No } & \multicolumn{3}{c}{ Uraian } & \multicolumn{3}{l}{ Rata-rata } \\
\cline { 3 - 5 } & & $\begin{array}{c}\text { Harga Aktual } \\
(\mathrm{Rp} / \mathrm{kg})\end{array}$ & $\begin{array}{l}\text { Harga Mimum } \\
\text { Layak (Rp kg) }\end{array}$ & Selisih \\
\hline 1 & $\begin{array}{l}\text { Gabahh Kering Panen } \\
\text { (GKP) }\end{array}$ & 3.217 & 2.666 & 551 \\
2 & Beras & 6.434 & 3.754 & 2.680 \\
\hline
\end{tabular}

Sumber : Data Primer diolah, 2014.

Berdasarkan tabel diatas rata-rata harga aktual atas gabah kering panen (GKP) di Desa Pahang Asri adalah Rp.3.217/kg dan rata-rata harga minumum layak di tingkat petani adalah $\mathrm{Rp}$. 2.666,-/kg sehingga terdapat selisih Rp. 551,-/kg, sedangkan harga aktual beras sebesar Rp. 6.434,$/ \mathrm{kg}$, dan harga minumum layak di tingkat petani sebesar Rp. 3.754/kg, terdapat selisih sebesar Rp 12.680,-per kg. Hal ini menunjukkan bahwa harga aktual gabah kering panen (GKP) maupun harga aktual beras yang diterima petani selama ini sudah baik, karena harga aktual lebih tinggi dibandingkan harga minimum layak maupun harga pada posisi Break Even Poin (BEP).

Hasil analisis statistik menggunakan uji $\mathrm{T}$ test pada harga aktual dan harga minimum layak di tingkat petani atas gabah kering panen (GKP) (Lampiran 22) diperoleh nilai thitung sebesar 10,777 dan nilai $t_{\text {tabel }}$ pada tingkat signifikansi $\alpha=5 \%$ dan derajat bebas $(\mathrm{db}=37)$ diperoleh nilai 1,687. Hasil ini menunjukkan bahwa $t_{\text {hitung }}>t_{\text {tabel }}(10,777$ $>1,687$ ) yang berarti bahwa terdapat perbedaan yang signifikan antara harga aktual dan harga minimum layak di tingkat petani atas gabah kering panen (GKP). Pada tabel Paired Samples Statistic terlihat rata-rata harga aktual atas gabah kering panen (GKP) sebesar Rp.3.217,11/kg dan untuk harga minimum layak atas gabah kering panen (GKP) sebesar Rp.2.666,29/kg. Hal ini menunjukkan bahwa harga aktual atas gabah kering panen (GKP) lebih tinggi dibandingkan harga minimum layak atas gabah kering panen (GKP).

Berdasarkan data diatas dapat dikatakan bahwa jika produktivitas hasil gabah kering panen (GKP) sebesar $6.468 \mathrm{~kg}$ per hektar per musim tanam dan petani menjual gabah kering panen (GKP) dengan harga minimum sebesar Rp.2.666,29 per kg, maka petani di Desa Pahang Asri sudah memperoleh keuntungan karena harga tersebut lebih tinggi dibandingkan harga pada poisisi Break Even Poin (BEP) yaitu sebesar Rp. $1.303,-/ \mathrm{kg}$. Selain itu, petani di Desa Pahang Asri ini dengan jumlah tanggungan sebanyak 5 orang masih dapat memenuhi kebutuhan hidup minumumnya.
Hasil analisis statistik menggunakan uji $\mathrm{T}$ test pada harga aktual dan harga minimum layak di tingkat petani atas beras diperoleh nilai thitung sebesar 70,430 dan nilai $t_{\text {tabel }}$ pada tingkat signifikansi $\alpha=5 \%$ dan derajat bebas $(\mathrm{db}=37)$ diperoleh nilai 1,687. Hasil ini juga menunjukkan bahwa $t_{\text {hitung }}>t_{\text {tabel }}(70,430>1,687)$ yang berarti bahwa terdapat perbedaan yang signifikan antara harga aktual dan harga minimum layak di tingkat petani atas beras. Pada tabel Paired Samples Statistic terlihat rata-rata harga aktual beras sebesar Rp.6.434,21/kg dan untuk harga minimum layak beras sebesar Rp.3.753,63/kg. Hal ini menunjukkan bahwa harga aktual atas beras lebih tinggi dibandingkan harga minimum layak atas beras.

Data di atas menunjukkan bahwa jika produktivitas hasil beras sebesar $3.849 \mathrm{~kg}$ per hektar per musim tanam dan petani menjualnya dengan harga minimum sebesar Rp. 3.754 per kg, maka petani di Desa Pahang Asri sudah memperoleh keuntungan karena harga tersebut lebih tinggi dibandingkan harga pada poisisi Break Even Poin (BEP) yaitu sebesar Rp. 2.929,-$/ \mathrm{kg}$. Selain itu, petani di Desa Pahang Asri ini dengan jumlah tanggungan sebanyak 4 orang masih dapat memenuhi kebutuhan hidup minumumnya.

\section{IV.KESIMPULAN DAN SARAN}

\section{A. Kesimpulan}

Berdasarnya hasil penelitian dan analisis yang telah dilakukan, maka dapat ditarik kesimpulan sebagai berikut:

1. Rata-rata harga minimum layak di tingkat petani atas gabah kering panen (GKP) sebesar Rp. $2.666 / \mathrm{kg}$ dan harga minimum layak di tingkat petani atas beras sebesar Rp. 3.754,-/kg. Kedua harga minimum layak di tingkat petani tersebut lebih rendah dari harga aktual yang besarnya adalah $\mathrm{Rp} 3.217,-$ per $\mathrm{kg}$ untuk gabah kering panen (GKP) dan Rp. 6.434,- per $\mathrm{kg}$ untuk beras.

2. Terdapat perbedaan antara harga aktual dan harga minimum layak di tingkat petani atas gabah kering panen (GKP). Pada tabel Paired Samples Statistic terlihat rata-rata harga aktual atas gabah kering panen (GKP) sebesar Rp.3.217,11/kg dan untuk harga minimum layak atas gabah kering panen (GKP) sebesar Rp.2.666/kg. Hal ini menunjukkan bahwa harga aktual atas gabah kering panen (GKP) 
lebih tinggi dibandingkan harga minimum layak atas gabah kering panen (GKP).

3. Terdapat perbedaan antara harga aktual dan harga minimum layak di tingkat petani atas beras. Pada tabel Paired Samples Statistic terlihat rata-rata harga aktual beras sebesar Rp.6.434,21/kg dan untuk harga minimum layak beras sebesar Rp. 3.754/kg. Hal ini menunjukkan bahwa harga aktual atas beras lebih tinggi dibandingkan harga minimum layak atas beras.

\section{B. Saran}

1. Meskipun harga minimum layak di tingkat petani lebih rendah dibandingkan harga aktual, disarankan kepada petani untuk memaksimalkan penggunaan pendapatan dan sisa pendapatan untuk meningkatkan kesejahteraannya.

2. Pada dasarnya perbedaan harga minimum layak pada petani yang menjual gabah kering panen (GKP) dan yang menjual beras disebabkan oleh jumlah produksi yang dihasilkan dan jumlah biaya total yang dikeluarkan, maka sebaiknya petani dapat memaksimalkan efisiensi penggunaan biaya produksi dengan tetap mempertahankan jumlah produksi yang dihasilkan.

\section{DAFTAR PUSTAKA}

Agustinus, M. 2016. Pemerintah Putuskan HPP Beras Tahun ini Tetap Rp.7.300,-/Kg. Detikfinance. Diakses 22 Maret 2016.

Amang, Beddu dan M. Husein Sawit. 1999. Kebijakan Beras dan Pangan Nasional. IPB Press. Bogor.

Antoni, M. 2006. Analisis Determinan Keputusan Petani dam Produksi Bahan Olah Karet serta Hubungannya dengan Pendapatan di Desa Sri Kembang Kecamatan Tanjung Batu Kabupaten Ogan Ilir. Jurnal Agribisnisndan Industri Pertanian. Vol. 5, No. 1. Juli 2006. Fakutas Pertanian UNSRI. Palembang.

BPS. 2013. Sensus Partanian 2013. BPS Propinsi Sumatera Selatan. Palembang.

BPS. 2013. Statistik Pengeluaran Penduduk OKU Timur. BPS Kabupaten OKU Timur. Martapura.

BPS. 2013. Produksi Padi, Jagung dan Kedelai Sumatera Selatan Angka Sementara. Berita Resmi Statistik BPS Sumatera Selatan Nomor 18/03/16/Th. XVIII, 01 Maret 2014.
Hernanto, F. 1989. Ilmu Usahatani. Penebar Swadaya. Jakarta.

Hutagalung,M., 2007. Dampak Peningkatan Harga Beras Terhadap Tingkat Kesejahteraan Petani pada Beberapa Strata Luas lahan. Skripsi. Departemen Sosial Ekonomi, Fakultas Pertanian, Universitas Sumatera Utara. Medan.

Irianto, G.E. Sumarni dan E. Pasandaran. 2004. Dinamika Iklim dan Sumberdaya Air untuk Budidaya Padi dalam Ekonomi padi dan Beras Indonesia. Badan Penelitian dan Pengembangan Pertanian. Jakarta.

Lipsey, G.R. Courant, N.P. Purvis, D.D. Steiner, O.P. 1995. Pengantar Mikroekonomi (Jilid Satu). Binarupa Aksara. Jakarta.

Masyhudi, M.F. 1992. Penerapan Bioteknologi dalam Pengembangan Padi Bulu. Pusat Penelitian dan Pengembangan Tanaman Pangan. Jakarta.

Prawirokusumo. 2009. Ilmu Usahatani. Bumi Aksara. Jakarta.

Pusdatin. 2014a. Statistik Makro Sektor Pertanian. Kementerian Pertanian. Jakarta.

Pusdatin. 2014b. Statistik Pertanian 2014. Pusat Data dan Informasi Pertanian Kementerian Pertanian. Jakarta.

Rahim, M. 2010. Dampak Kebijakan Harga dan Impor Barang terhadap Nilai Tukar Petani di Pantai Utara Jawa Barat. Trikonomika Volume 9 No. 1. 1 Juni 2010. Hal. 29-36.

Sangadji, EM dan Sopiah. 2010. Metodologi Penelitian. Penerbit Andi. Yogyakarta.

Soekartawi, Dillon JL, Hardaker JB, Soeharjo A. 1986. Ilmu Usahatani dan Penelitian Untuk Perkembangan Petani Kecil. Universitas Indonesia Press. Jakarta.

Soekartawi. 2002. Analisis Usahatani. UI Press. Jakarta.

Sopian, D. 2008. Analisis Harga Gabah dan Tingkat Pendapatan Petani di Lokasi Program Dana Penguatan Modal Lembaga Ekonomi Usaha Pedesaan (LUEP). (Kasus di Kecamatan Pameungpeuk dan Bale Endah Kabupaten Bandung). Skripsi. Program Studi Ekonomi Pertanian dan Sumberdaya. Fakultas Pertanian IPB. Tidak Dipublikasikan.

Sumardjono. D. 2004. Diktat Kuliah Ekonomi Produksi. Program Study Sosial Ekonomi Peternakan. Fakultas Peternakan Universitas Diponegoro. Semarang.

Sumarwan, U. 2004. Perilaku Konsumen Teori Dan Penerapannya Dalam Pemasaran . Ghalia Indonesia. Bogor. 
Suratiyah, K. 2009. Ilmu Usahatani. Penebar Swadaya. Jakarta.

Suryana, A., S. Mardianto dan M. Ikhsan. 2001. Bunga Rampai Ekonomi Beras. Lembaga Penyelidikan Ekonomi dan Masyarakat,
Fakultas Ekonomi, Universitas Indonesia. Jakarta.

Verina H. Secapramana, 2001. Model dalam strategi penetapan harga. Unitas Vol.. 9. No. 1. September 2000 - Pebruari 2001, 30-43. 